\title{
Competition Conditions in Taiwan's Public Accounting Industry
}

\author{
Bao-Guang Chang ${ }^{1}$, Tai-Hsin Huang ${ }^{2} \&$ Hsiu-Mei Wang ${ }^{1}$ \\ ${ }^{1}$ Department of Accounting, Tamkang University, New Taipei City, Taiwan \\ ${ }^{2}$ Department of Money and Banking, National Chengchi University, Taipei, Taiwan \\ Correspondence: Bao-Guang Chang, Department of Accounting, Tamkang University, New Taipei City, Taiwan. \\ No.151, Yingzhuan Rd., Danshui Dist., New Taipei City 25137,Taiwan( R.O.C)
}

Received: December 3, 2016

Accepted: December 16, 2016 Online Published: December 28, 2016

doi:10.5430/afr.v6n1p43

URL: http://dx.doi.org/10.5430/afr.v6n1p43

\begin{abstract}
This paper investigates the degree of market competition in the public accounting industry of Taiwan over the period 1994-2008, using the 'H statistic' proposed by Panzar \& Rosse (1987). Differing from previous works, this paper applies a newly developed model, i.e., the censored stochastic frontier (CSF) model, to test whether the audit market has achieved its long-run equilibrium. The model is superior to the conventional model that requires researchers adding a unity to the dependent variable of returns on assets (ROA) for all observations, forcing the transformed dependent variable to be non-negative. One can then take the natural logarithm of this dependent variable. Evidence shows that Taiwan's accounting industry is characterized as monopolistic competition with a trend towards perfect competition. The result will help to build up the empirical model for public accounting industry. The CSF model confirms that this industry is already in a long-run equilibrium in the second half of the sample, which validates the use of the Panzar-Rosse model. Conversely, the employment of the conventional approach leads to a rejection of the long-run equilibrium over the entire sample period.
\end{abstract}

Keywords: Public accounting industry, Degrees of competition, H statistic, Panzar-Rosse model, Long-run equilibrium, Censored stochastic frontier model

\section{Introduction}

The public accounting industry provides transparent and accurate financial information to both listed firms and investors. This helps listed firms obtain needed funds from the capital markets. The industry's services also contribute to the economic development of a country. Therefore, this industry plays a critical role in smoothing out the operations of capital markets.

With the development of capital markets around the world and the growing demand for professional audit services, the accounting industry has become a competitive profession in almost all countries (e.g., Simunic, 1980; Banker et al., 2003; Banker et al., 2005), including Taiwan. Taiwan's accounting industry has experienced a series of major changes in the last two decades. For instance, the Ministry of Examination drastically raised the pass rate for the examination of certified public accountants (CPAs) in 1989; Taiwan's CPA Association cancelled the audit fee floor in 2001; the Certified Public Bookkeepers Act was enacted in 2004. Moreover, the central government implemented "Go West and South" trade policies during the same period, motivating a large number of Taiwanese firms to move and/or invest into China or countries in Southeast Asia for business expansion. As a result, the demand for local accounting services shrank significantly.

The above-mentioned policy changes have caused an increase in the supply of CPAs and a decrease in the demand for accounting services. Whether these changes intensify the competition conditions in the industry is an important issue worth examining. This issue relates to whether the accounting industry can provide services needed by local businesses and achieve an optimal allocation of resources at the same time. To the best of our knowledge, few research works have applied a valid approach to study the related issues for this industry. Therefore, results of this paper are expected to offer valuable references for managers of CPA offices and government authorities, as well as to contribute to the healthy development of the public accounting industry.

The main purpose of this study is to assess the degree of market competition in Taiwan's public accounting industry during 1992-2008, using the non-structural Panzar-Rosse approach (Panzar \& Rosse, 1987). In addition to the impact of policy changes on competition, this study also investigates the differences between results obtained using this 
non-structural index and the results obtained using structural indices, such as the concentration ratio of the top five firms (CR5) and the Herfindahl-Hirschman index (HHI).

The appropriateness of the PR approach depends on if the market is in a long-run equilibrium. To confirm if this state is achieved, previous works ran the natural logarithm of returns on assets (ROA) on the natural logarithm of factor prices and tested if the sum of the estimated coefficients of all the factor prices equals zero. If the sum equals zero, then the market is said to be in a long-run equilibrium; otherwise, the market fails to be in a long-run equilibrium. Unfortunately, some of our sample firms earn negative profits, for which we cannot take the natural logartihm of the negative number. To address this problem, some scholars proposed to add 1 to the ROA of each sample to make all sample firms have a positive value of $1+\mathrm{ROA}$, before taking the natural logarithm and conducting regression analysis. Obviously, this conventional method distorts information carried by the sample and causes biased parameter estimates. The reliability of the test for long-run equilibrium is therefore questionable.

The main difference between this research and previous papers lies in the application of the censored stochastic frontier model (CSF), first proposed by Tsay et al. (2012), to test for long-run equilibrium, under the framework of Panzar and Rosse (1987) [henceforth, the PR approach]. The main advantage of this model is that it produces consistent coefficient estimates without requiring, like conventional models do, that a unity be added to each sample firm's ROA.

The rest of the paper is organized as follows. Section 2 briefly reviews the past literature. Section 3 introduces our empirical models. Section 4 describes data sources. Section 5 analyzes empirical results, while the last section concludes the paper.

\section{Literature Review}

\subsection{Market Competition}

There are two approaches to assessing the degree of market competition: the structural approach and non-structural approach. The former approach stems from the structure-conduct-performance (SCP) hypothesis, which asserts that market structure is a key factor affecting the market behavior and performance of a firm, and market competition can be estimated using market structure indices (e.g., Gilbert, 1984; Hannan, 1991).

Empirical findings are mixed regarding the SCP hypothesis. Results that reject the hypothesis are typically explained by the contestable theory (Baumol, 1982) and the efficiency hypothesis (Demsetz, 1974). Given free market entry and exit, the contestable theory claims that firms are unlikely to raise product prices even if the market is highly concentrated, due to the threat of potential entrants. Therefore, the market can still be characterized as perfect competition. The efficiency hypothesis suggests that the increase in market concentration may arise from the strategic decision of more efficient firms to increase market share. As a result, competition will not decrease with the increase of market concentration.

Later researchers estimated the degree of competition using an econometric model, which can be classified as a non-structural approach. The most well-known papers that use the non-structural approach include Bresnahan (1982), Lau (1982), and Panzar and Rosse (1987). On the condition that the market is in long-run equilibrium, the PR approach is established on the idea that market power is measured by the extent to which changes in input prices are reflected by the equilibrium revenues received by a firm. Shaffer (1982) was the first scholar to apply the PR approach for analyzing competition in the banking industry. Most researchers employed data obtained from the U.S. or European nations, and only a few assessed the competitive conditions in Asia or other regions. Some researchers recently attempted to investigate competition across nations or regions - see, for example, Molyneux et al. (1996), Vesala (1995), Hondroyiannis et al. (1999), Hempell (2002), Coccorese (2004, 2009), Matthews et al. (2007), Molyneux et al. (1994), Casu and Girardone (2006), Bikker and Haaf (2002), Gelos and Roldós (2004), Turk-Ariss (2009), Yeyati and Micco (2007), and Claessens and Laeven (2004).

The Lerner index is another indicator of market structure, drawing much attention from academic researchers, and is a strongly established measure of market power at the firm level. For instance, Fernández et al. (2005) assessed market power for the banking sectors in Europe, including Germany, France, Italy, United Kingdom, and Spain. Fernández et al. (2007) investigated competition among 15 European nations during 1993-2001 and found an upward trend of market power. Carbo et al. (2009) examined the correlation between structural and non-structural approaches for banks in 14 European nations, with results showing no significant correlation between structural measures (net interest margin/total asset ratio (NTMTA), ROA, and HHI) and non-structural measures (H statistic and Lerner index). Berger et al. (2009) and Turk-Ariss (2010) both applied the Lerner index to explore the relationship between competition and market stability among banking sectors across countries. Berger et al. (2009) found higher market 
power led to higher loan risk, but lower risk exposure. From a sample of banks across 60 countries during 1999-2005, Turk-Ariss (2010) noted that higher market power led to higher market stability (Z-index) and profit efficiency.

This review shows that most previous single-country or cross-country studies on the issue of market competition focused on the banking or insurance sectors in the U.S. or in European nations. This paper shall examine competition in the accounting profession in Taiwan, a non-Western country. Hence, the results of this paper help fill some gaps in the extant literature.

\subsection{Taiwan's CPA Industry}

\subsubsection{A General Overview of the Industry}

Information symmetry is one of the keys to successful financing in capital markets. To achieve information symmetry, firms are legally required to have their financial statements reviewed and attested by CPAs.

In the audit market, different types of CPA firms provide attestation services and non-audit services, with each one having its own specific characteristics. Large CPA firms that operate in an alliance particularly play a critical role in providing these services. The 2005 Survey Report on the Business of CPA Firms, published by Financial Supervisory Commission, Executive Yuan in March 2007, shows that only 13 of 801 CPA firms in Taiwan (1.62\%) generate annual revenue exceeding NT $\$ 100$ million. However, the accounting professionals working for these large CPA firms account for nearly half of the accounting population (49\%) in Taiwan. These statistics reveal that most CPA firms in Taiwan are small, and the market is dominated by large firms.

In terms of organizational structure, larger CPA firms are usually formed as a partnership and take the largest share of revenue and employment. As of 2005, the numbers of partnership-based and sole-proprietorship-based CPA firms were respectively 246 and 555 (a ratio of about 1:2.3). However, the former type of CPA firms had an average number of employees of 54 persons, while the latter had only an average of 6 (a ratio of 9:1). In terms of average revenue from professional services, the former type of CPA firms (NT\$65.82 million) generated about 18 times more revenue than the latter (NT\$3.73 million). These statistics confirm that partnership-based CPA firms are the backbone of Taiwan's accounting industry.

In 2005 CPA firms generated most of their revenue from audit services (72.6\%), while only $27.4 \%$ of their revenue came from non-audit services. Their primary audit services were IPO attestation (21.7\%) and filing income tax reports $(22.3 \%)$. The rest of their audit-related revenue was earned from bank accommodation (13.0\%) and attestation of other financial reports (15.6\%).

\subsubsection{Market Competition}

Using audit fee data, Simunic (1980) found that the largest eight accounting firms in the U.S. were actually not monopolizing the audit market. The audit market was instead a highly competitive market with fierce price competition. Porter (1985) analyzed the competitive strategies of the top six CPA firms to explain auditor industry specialization. He suggested that specialization helps firms maintain competitive advantages, and audit pricing is usually associated with specialization and negotiation abilities. Banker et al. (2005) pointed out that global competition and technical changes have strongly impacted the public accounting industry. Banker et al. (2003) mentioned that most CPA firms pursue economies of scale to cope with competition. Banker et al. (2005) found among the top $100 \mathrm{CPA}$ firms in the U.S. that productivity increases are mainly associated with technical improvement rather than relative efficiency change.

In order to initiate adequate industry policies, Taiwan's authorities have been continuously gathering relevant data for this industry since 1989. Therefore, this dataset is suitable for systematic research on issues such as competition and others. The variables provided by the data will be described later.

\section{Empirical Model}

\subsection{The PR Test}

The PR approach assumes that all firms pursue profit maximization. To compute the $H$ statistic one first regresses $(\log )$ total revenue on a set of $(\log )$ factor prices, together with some control variables, and then sums over the parameter estimates of these factor prices. A value of $H \leqq 0$ indicates a monopoly or a perfect cartel. A value of $H=1$ indicate, where the firm's revenue does not increase proportionally with the increase of input prices. Table 1 summarizes the above discussion. 
Table 1. Meanings of the $\mathrm{H}$ statistic

\begin{tabular}{ll}
\hline$H$ statistic & Competitive structure \\
\hline$H \leqq 0$ & Monopoly \\
$0<H<1$ & Monopolistic competition \\
$H=1$ & Perfect competition \\
\hline
\end{tabular}

The PR approach specifies the marginal cost (MC) as a log-linear equation as follows:

$$
\ln M C=\alpha_{0}+\alpha_{1} \ln Q+\sum_{i=1}^{m} \beta_{i} \ln W_{i}+\sum_{j=1}^{p} \gamma_{j} \ln E X_{j}^{\text {Cost }}
$$

where $Q$ denotes quantity of output, $W$ is an $m$-vector of input prices, including labor and capital, $E X^{\text {Cost }}$ refers to all exogenous factors that affect the cost function, and $\alpha, \beta$, and $\gamma$ are the corresponding parameters. The PR approach also assumes that a CPA firm's marginal revenue (MR) is a log-linear equation expressed as:

$$
\ln M \mathrm{R}=\delta_{0}+\delta_{1} \ln Q+\sum_{k=1}^{q} \lambda_{k} \ln E X_{K}^{R E V}
$$

where $E X^{R E V}$ is an exogenous variable affecting the demand for the CPA firm, and $\delta$ and $\lambda$ are parameters. A profit-maximizing firm follows the principle of $M C=M R$ to determine its optimal output $\left(Q^{*}\right)$ :

$$
\ln Q^{*}=\left(\alpha_{0}-\delta_{0}+\sum_{i=1}^{m} \beta_{i} \ln W_{i}+\sum_{j=1}^{p} \gamma_{j} \ln E X_{j}^{\text {Cost }}-\sum_{k=1}^{q} \lambda_{k} \ln E X_{k}^{R E V}\right) /\left(\delta_{1}-\alpha_{1}\right)
$$

Let the logarithm of the inverse demand function be $\ln P=\phi+\varphi \ln Q$, where $P$ denotes the output price. At the market equilibrium, the logarithm of total revenue $(R E V)$ can be expressed as $\ln R E V^{*}=\ln \left(P^{*} Q^{*}\right)=\phi+(\varphi+1) \ln Q^{*}$, meaning that total revenue is a function of input prices and some other exogenous variables affecting production cost and demand.

To examine the competition in Taiwan's accounting profession, we use the reduced-form revenue equation as follows:

$$
\begin{aligned}
& \ln T R T A=\alpha_{0}+\alpha_{1} \ln W_{1}+\alpha_{2} \ln W_{2}+\alpha_{3} \ln W_{3}+\alpha_{4} \ln C R_{5}+\alpha_{5} \ln A G E \\
& +\alpha_{6} \ln \mathrm{HC}+\alpha_{7} \mathrm{BRANCH}+e \\
& H=\alpha_{1}+\alpha_{2}+\alpha_{3}
\end{aligned}
$$

where $\alpha$ is a vector of regression coefficients, and total revenue (TR) consists of revenues from both audit and non-audit services. According to Al-Muharrami et al. (2006), we divide TR by total assets (TA) to normalize it, and the new variable is referred to as TRTA, which is the dependent variable in (4).

Equation (4) contains four control variables. In the public accounting industry, labor and capital are the primary input factors, while partners have decisive influences on the operation and performance of the firm. Therefore, the labor input consists of the numbers of partners and non-partners. The unit price of partners $\left(W_{1}\right)$ is defined as the total payment to partners divided by the number of partners. The unit labor price of non-partners $\left(W_{2}\right)$ is defined as total payment to non-partners divided by number of non-partners. The unit floor area price $\left(W_{3}\right)$ is calculated as the ratio of total expenses on rent, maintenance, amortization, and depreciation to the total floor area of the firm. Notation $e$ is random disturbances, reflecting all factors uncontrollable by the firm, and $\mathrm{H}$ is the $\mathrm{H}$-statistic as defined in Table 1.

The market share of the top five CPA firms $\left(C R_{5}\right)$ is a proxy variable for market concentration. Note that it can also be represented by the Herfindahl-Hirschman Index $(H H I)$. This variable is calculated based on the revenue of each firm. Other control variables that may affect firm revenue include firm age $(A G E)$, human capital $(H C)$, and number of branches $(B R A N C H)$. Table 2 defines the aforementioned variables. 
Table 2. Variable definition

\begin{tabular}{|c|c|c|}
\hline Variable & Description & Method of calculation \\
\hline TRTA & $\begin{array}{l}\text { Ratio of total revenue to total } \\
\text { assets }\end{array}$ & Total revenue / total assets \\
\hline$R O A$ & Return on assets & Net income / total assets \\
\hline$W_{1}$ & Unit labor price of partners & Payment to partners / number of partners \\
\hline$W_{2}$ & Unit labor price of non-partners & $\begin{array}{l}\text { Payment to non-partners / number of } \\
\text { non-partners }\end{array}$ \\
\hline$W_{3}$ & Unit floor area price & $\begin{array}{l}\text { Total expense on rent, maintenance, } \\
\text { depreciation, and amortization / total floor area } \\
\text { used by the firm }\end{array}$ \\
\hline$C R_{5}$ & $\begin{array}{l}\text { Concentration ratio of the top five } \\
\text { CPA firms }\end{array}$ & $\begin{array}{l}\text { Sum of market shares taken by the top five CPA } \\
\text { firms }\end{array}$ \\
\hline$H H I$ & Herfindahl-Hirschman index & $\begin{array}{l}\text { Sum of the squares of the market share of each } \\
\text { CPA firm }\end{array}$ \\
\hline$A G E$ & Age of the firm & $\begin{array}{l}\text { Number of years that the firm has been in } \\
\text { operation }\end{array}$ \\
\hline$H C$ & Human capital & $\begin{array}{l}\text { Calculated based on job experience, and the } \\
\text { number and the weight of each type of } \\
\text { employers (including partners, professionals, } \\
\text { and others) }\end{array}$ \\
\hline$B R A N C H$ & Number of branches & Number of branches that each CPA firm has \\
\hline
\end{tabular}

\subsection{Test for Long-run Equilibrium}

It should be noted that the $H$-statistic is derived on the condition of long-run equilibrium. In the absence of a long-run equilibrium, firms with poor performance may fail to quickly exit the market when factor prices increase. As a result, total revenue and factor prices become inversely related, causing overestimation of market power. Shaffer (1982) proposed to replace total revenue in Equation (4) with ROA on the grounds that ROA and factor prices are not correlated in long-run equilibrium. Nathan and Neave (1989), Molyneux et al. (1996), Bikker and Haaf (2002), Casu and Girardone (2006), and Schaeck et al. (2009) also adopted this concept. Equation (4) is re-written as:

$$
\begin{aligned}
& \ln R O A=\beta_{0}+\beta_{1} \ln W_{1}+\beta_{2} \ln W_{2}+\beta_{3} \ln W_{3}+\beta_{4} \ln C R_{5}+\beta_{5} \ln A G E \\
& +\beta_{6} \ln \mathrm{HC}+\beta_{7} \text { BRANCH }+v-u \\
& \mathrm{E}=\beta_{1}+\beta_{2}+\beta_{3}=0
\end{aligned}
$$

In Equation (6), $\beta$ is a 7-vector of regression coefficients, and all explanatory variables are the same as in (4). Here, $u \sim N^{+}\left(0, \sigma_{u}^{2}\right)$ is a non-negative random variable with zero mean and constant variance, called profit inefficiency. This term reflects profit loss due to the presence of technical inefficiency; $v \sim N\left(0, \sigma_{v}^{2}\right)$ is a random disturbance with zero mean and constant variance. Assume $v$ and $u$ are statistically independent. If the null hypothesis of $\mathrm{E}=0$ holds, then the changes in factor prices do not affect ROA, implying that the market is in a long-run equilibrium. Conversely, the rejection of this hypothesis implies that long-run equilibrium is not achieved.

It should be noted that some sample firms may have a negative ROA due to losses. In such case, we cannot take a natural logarithm with respect to them. Most previous studies replaced ROA by $(1+\mathrm{ROA})$ to avoid this problem, but this method may severely distort the sample information. If the dependent variable lnROA in Equation (6) is replaced by $\ln (1+\mathrm{ROA})$, then it is easy to show that the parameter estimates are inconsistent. Consequently, the result inferred from Equation (7) will not be correct. In this paper, we attempt to solve this difficulty by introducing the censored stochastic frontier model (CSF), proposed by Tsay et al. (2013), as CSF allows for truncation of the dependent variable in (6) at a constant value, say $c$. The CSF model must be estimated by maximum likelihood, and so the 
consistency of the estimated coefficients can be ensured. The application of the CSF model is the major difference of this research from previous ones.

Below is a brief explanation of how the probability density function in the CSF model is derived. Please refer to Tsay et al. (2013) for more details. It is well-known that the probability density function of composite error $\varepsilon_{i}=v_{i}-u_{i}$ for firm $i$ can be expressed as follows:

$$
f\left(\varepsilon_{i}\right)=\frac{2}{\sigma} \varphi\left(\frac{\varepsilon_{i}}{\sigma}\right) \Phi\left(-\frac{\lambda \varepsilon_{i}}{\sigma}\right)
$$

where $\lambda=\sigma_{u} / \sigma_{v}$, and $\sigma^{2}=\sigma_{v}^{2}+\sigma_{u}^{2}$. Assume that the dependent variable in (6) is truncated at a constant value of $c$. According to Amemiya (1985), the log-likelihood function of the CSF model can be expressed as follows:

$$
L=\sum_{y_{i}>c} \ln \left(f\left(\varepsilon_{i}\right)\right)+\sum_{y_{i}=c} \ln \left(F\left(c-x_{i} \beta\right)\right)
$$

where $y_{i}=R O A$, and $x_{i}$ and $\beta$ denote a vector of independent variables and the corresponding vector of regression coefficients on the right side of (6). The first term after the equation sign sums up all the samples with $y_{i}>c$, and the second term sums up all the samples with $y_{i}=c$ (corresponding to those firms that incur losses).

Let $Q_{i}=c-x_{i} \beta$, and $F\left(Q_{i}\right)=\int_{-\infty}^{Q_{i}} f\left(\varepsilon_{i}\right) d \varepsilon_{i}=\frac{2}{\sigma} I\left(Q_{i}\right)$ is the cumulative distribution function of $\varepsilon_{i}$. Define $I\left(Q_{i}\right)$ as:

$$
I\left(Q_{i}\right)=\int_{-\infty}^{Q_{i}}\left(\int_{-\infty}^{-\frac{\lambda \varepsilon_{i}}{\sigma}} \varphi(\xi) d \xi\right) \varphi\left(\frac{\varepsilon_{i}}{\sigma}\right) d \varepsilon_{i}=\int_{-\infty}^{Q_{i}}\left(\int_{-\infty}^{a \varepsilon_{i}} \varphi(\xi) d \xi\right) \varphi\left(b \varepsilon_{i}\right) d \varepsilon_{i}
$$

where $a=-\lambda / \sigma<0$, and $b=1 / \sigma$.

Equation (10) has no closed form, causing the maximum likelihood method to not be applicable. To solve this problem, Tsay et al. (2013) derived an approximation function to $I\left(Q_{i}\right)$, that is, $I_{a p p}\left(Q_{i}\right)$. By replacing $I\left(Q_{i}\right)$ with $I_{a p p}\left(Q_{i}\right)$, we can estimate regression coefficients by maximum likelihood. In short, $I_{a p p}\left(Q_{i}\right)$ can be expressed as:

$$
\begin{aligned}
I_{a p p}\left(Q_{i}\right) & =\frac{1}{2 b}\left[1+\operatorname{erf}\left(\frac{b Q_{i}}{\sqrt{2}}\right)\left(\frac{1-\operatorname{sign}\left(Q_{i}\right)}{2}\right)\right] \\
& \left.\left.-\frac{1}{4 \sqrt{b^{2}-a^{2} c_{2}}} \exp \left(\frac{a^{2} c_{1}^{2}}{4\left(b^{2}-a^{2} c_{2}\right.}\right)\right\} 1+\operatorname{erf}\left[\frac{-a c_{1}-\sqrt{2} Q_{i}\left(b^{2}-a^{2} c_{2}\right) \operatorname{sign}\left(Q_{i}\right)}{2 \sqrt{b^{2}-a^{2} c_{2}}}\right]\right\}
\end{aligned}
$$

where the error function $\operatorname{erf}\left(z_{i}\right)$ is defined as:

$$
\begin{aligned}
\operatorname{erf}\left(\mathrm{z}_{i}\right) & =\frac{2}{\sqrt{\pi}} \int_{0}^{z_{i}} e^{-t^{2}} d t=2 \int_{0}^{\sqrt{2} z_{i}} \phi(t) d t \\
& =2 \Phi\left(\sqrt{2} z_{i}\right)-1 \\
& \approx 1-\exp \left(c_{1} z_{i}+c_{2} z_{i}^{2}\right)=g\left(z_{i}\right)
\end{aligned}
$$

The sign function $\operatorname{sign}\left(Q_{i}\right)=1,0,-1$, depending on $Q_{i}>0,=0,<0$. Tsay et al. (2013) showed that the choice of constants $c_{1}=-1.09500814703333$ and $c_{2}=-0.75651138383854$ is to ensure that the error function $\operatorname{erf}(z)$ can be best approximated by $g(z)$, for $z \geq 0$. Tsay et al. (2013) used simulations to prove that 
$F_{a p p}\left(Q_{i}\right)=\frac{2}{\sigma} I_{a p p}\left(Q_{i}\right)$ delivers a very accurate approximation to $F\left(Q_{i}\right)$ that cannot be exactly known. Moreover, Tsay et al. (2013) verified that the finite sample performance of the ML estimators of CSF based on $F_{\text {app }}\left(Q_{i}\right)$ is very promising under various model specifications.

\section{Data Sources}

The data used in this research were obtained from the Survey Reports on the Business of CPA Firms, published by Financial Supervisory Commission, Executive Yuan, spanning 1992-2008. The subjects in the survey were registered CPA firms in Taiwan. Missing data were excluded. The final sample consisted of 8,265 firm-year observations.

During the 17 years, many significant events occurred, such as a large number of local firms moving abroad, cancellation of the audit fee floor, and legislation through the Certified Bookkeepers Act. Therefore, we segmented the sample period into four sub-periods, including 1992-1996, 1997-2000, 2001-2004, and 2005-2008, so as to avoid possible structural changes.

Table 3 shows the market share of the top $5\left(\mathrm{CR}_{5}\right)$ and top $10\left(\mathrm{CR}_{10}\right) \mathrm{CPA}$ firms during 1992-2008, as well as HHI. During the sample period, $\mathrm{CR}_{5}$ initially decreased from $40.72 \%$ to $35.80 \%$ in 1994 and then increased steadily to $68.43 \%$ in 2008. This tendency shows that the top 5 CPA firms in Taiwan have seized high market power at the end of the sample period. The top $10 \mathrm{CPA}$ firms showed a similar trend for market share. They had a market share of $72.18 \%$ in 2008 , or only $3.75 \%$ more than that held by the top 5 firms.

A value of HHI smaller than 1,000 means low market concentration, HHI between 1,000-1,800 means intermediate market concentration, and HHI greater than 1,800 means high market concentration. The higher the concentration is, the lower is the competition. $\mathrm{HHI}$ also had a similar trend for $\mathrm{CR}_{5}$ and $\mathrm{CR}_{10}$ and was less than 1000 before 2002. It exceeded 1000 after 2003, began to soar after 2006, and finally reached 1,309 in 2008. Market concentration was not concentrated before 2002, but moderately concentrated after 2003 .

Table 3. Descriptive statistics of the structure of Taiwan's public accounting market

\begin{tabular}{|c|c|c|c|c|}
\hline \multirow{2}{*}{ Year } & \multirow[t]{2}{*}{ Index } & \multicolumn{2}{|c|}{ Market share (\%) } & \multirow{2}{*}{ HHI } \\
\hline & & $\mathrm{CR}_{5}$ & $\mathrm{CR}_{10}$ & \\
\hline & 1992 & 40.7154 & 48.9866 & 398.7940 \\
\hline & 1993 & 37.2835 & 44.8898 & 347.1894 \\
\hline & 1994 & 35.7982 & 45.3757 & 313.9104 \\
\hline & 1995 & 36.4892 & 46.1742 & 325.5748 \\
\hline & 1996 & 39.6031 & 49.2090 & 376.0553 \\
\hline & 1997 & 39.5511 & 50.0225 & 372.2424 \\
\hline & 1998 & 41.7495 & 52.3367 & 403.3772 \\
\hline & 1999 & 49.0774 & 55.7789 & 524.8513 \\
\hline & 2000 & 51.0812 & 57.5448 & 569.0482 \\
\hline & 2001 & 59.7906 & 64.2161 & 777.6285 \\
\hline & 2002 & 59.2668 & 64.7463 & 746.0654 \\
\hline & 2003 & 59.3823 & 63.7100 & 1274.3958 \\
\hline & 2004 & 66.1114 & 70.1769 & 1169.5498 \\
\hline & 2005 & 63.4702 & 67.4630 & 1064.1144 \\
\hline & 2006 & 66.4645 & 70.3407 & 1201.1790 \\
\hline & 2007 & 67.2419 & 71.0322 & 1255.0802 \\
\hline & 2008 & 68.4300 & 72.1762 & 1309.0250 \\
\hline
\end{tabular}

Figures 1 and 2 illustrate the above three indices. A turning point can be found in 2002, which may be associated with the cancellation of the audit fee floor in 2001. This policy was expected to increase market competition. The figures suggest that there was in fact a decline in market competition. This conclusion is inconsistent with the finding 
by the PR approach.

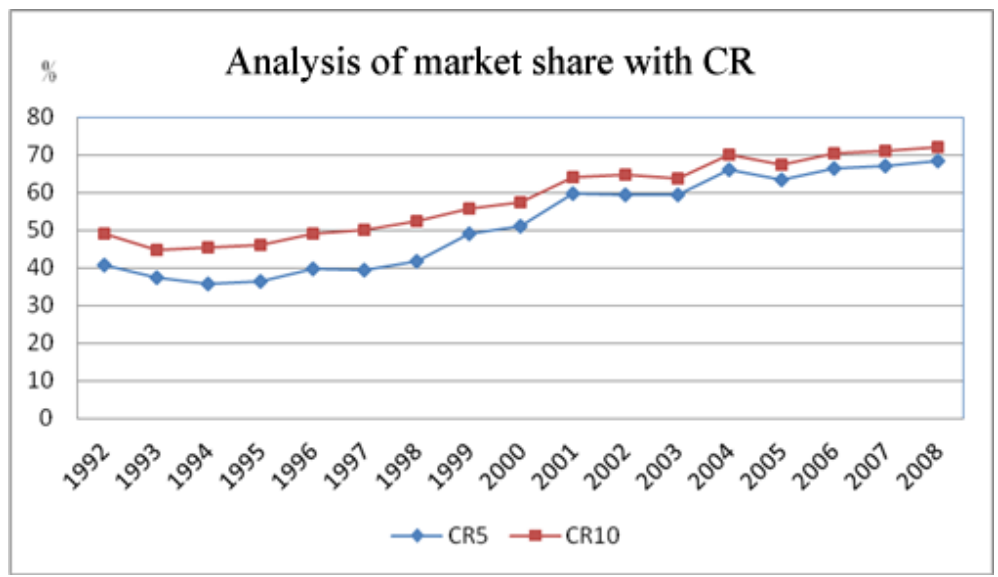

Figure 1. Trend of concentration ratios based on $\mathrm{CR}_{5}$ and $\mathrm{CR}_{10}$

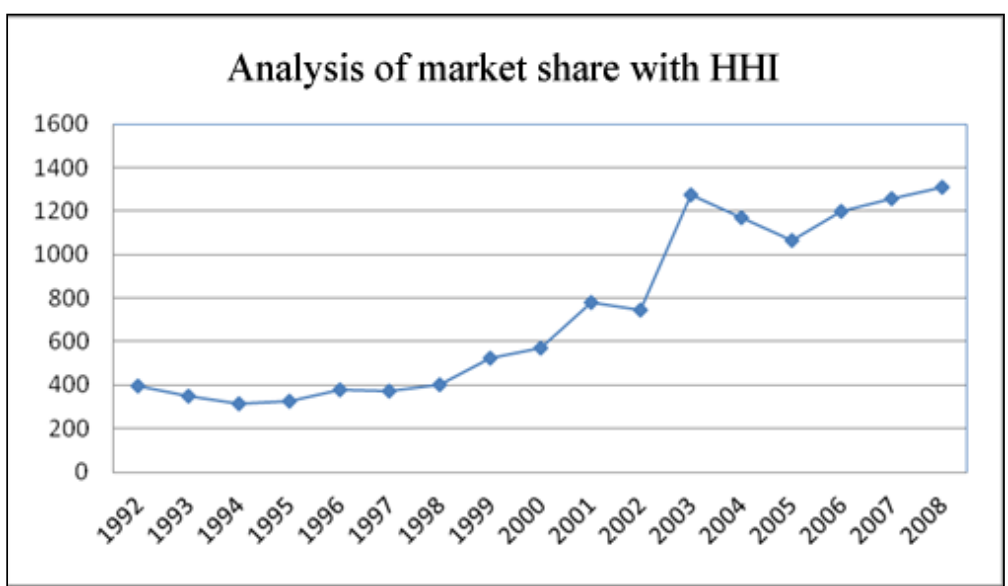

Figure 2. Trend of market concentration based on HHI

Table 4 presents the descriptive statistics of variables used in the regression analysis. The means of TRTA and ROA are equal to 1.0008 and 0.1764 , respectively. It should be noted that some CPA firms earned negative profits. Those firms' ROA is assigned a small value. Among the three inputs, the unit labor price of partners $\left(W_{1}\right)$ is approximately 3.16 times the unit labor price of non-partners $\left(W_{2}\right)$, which is a characteristic of the public accounting industry. The mean firm age is 12 years, meaning that most firms have accumulated abundant practical experiences. Finally, the mean number of branches (BRANCH) equals 0.26. 
Table 4. Descriptive statistics

\begin{tabular}{|c|c|c|c|c|c|c|c|c|}
\hline Year & TRTA & ROA & W1 & W2 & W3 & AGE & $\mathrm{HC}$ & BRANCH \\
\hline 1992 & $\begin{array}{c}0.5928 \\
(0.4473)\end{array}$ & $\begin{array}{c}0.1483 \\
(0.1604)\end{array}$ & $\begin{array}{r}1,237,329 \\
(1,197,306)\end{array}$ & $\begin{array}{c}294,957 \\
(141,607)\end{array}$ & $\begin{array}{c}0.0359 \\
(0.0316)\end{array}$ & $\begin{array}{l}10.1100 \\
(8.2860)\end{array}$ & $\begin{array}{c}7.9316 \\
(3.9868)\end{array}$ & $\begin{array}{c}0.2900 \\
(0.5550)\end{array}$ \\
\hline 1993 & $\begin{array}{c}0.6198 \\
(0.4667)\end{array}$ & $\begin{array}{c}0.1404 \\
(0.1380)\end{array}$ & $\begin{array}{c}1,231,747 \\
(1,161,497)\end{array}$ & $\begin{array}{c}323,174 \\
(159,519)\end{array}$ & $\begin{array}{c}0.0357 \\
(0.0343)\end{array}$ & $\begin{array}{c}9.6700 \\
(8.1990)\end{array}$ & $\begin{array}{c}7.3137 \\
(2.9472)\end{array}$ & $\begin{array}{c}0.2800 \\
(0.5430)\end{array}$ \\
\hline 1994 & $\begin{array}{c}0.6157 \\
(0.4495)\end{array}$ & $\begin{array}{c}0.1412 \\
(0.1410)\end{array}$ & $\begin{array}{c}1,244,978 \\
(1,147,085)\end{array}$ & $\begin{array}{c}330,494 \\
(140,300)\end{array}$ & $\begin{array}{c}0.0373 \\
(0.0342)\end{array}$ & $\begin{array}{c}9.6300 \\
(8.0290)\end{array}$ & $\begin{array}{c}7.4783 \\
(3.4710)\end{array}$ & $\begin{array}{c}0.2800 \\
(0.5590)\end{array}$ \\
\hline 1995 & $\begin{array}{c}0.6500 \\
(0.4442)\end{array}$ & $\begin{array}{c}0.1411 \\
(0.1371)\end{array}$ & $\begin{array}{c}1,198,451 \\
(1,097,511)\end{array}$ & $\begin{array}{c}336,940 \\
(145,871)\end{array}$ & $\begin{array}{c}0.0394 \\
(0.0338)\end{array}$ & $\begin{array}{c}9.5200 \\
(7.9230)\end{array}$ & $\begin{array}{c}7.1644 \\
(2.9743)\end{array}$ & $\begin{array}{c}0.2700 \\
(0.5400)\end{array}$ \\
\hline 1996 & $\begin{array}{c}0.6565 \\
(0.4331)\end{array}$ & $\begin{array}{c}0.1376 \\
(0.1229)\end{array}$ & $\begin{array}{c}1,249,204 \\
(1,136,189)\end{array}$ & $\begin{array}{c}332,581 \\
(133,100)\end{array}$ & $\begin{array}{c}0.0406 \\
(0.0339)\end{array}$ & $\begin{array}{c}9.8200 \\
(7.8850)\end{array}$ & $\begin{array}{c}6.7774 \\
(2.7495)\end{array}$ & $\begin{array}{c}0.2700 \\
(0.6000)\end{array}$ \\
\hline 1997 & $\begin{array}{c}0.6559 \\
(0.4359)\end{array}$ & $\begin{array}{c}0.1420 \\
(0.1318)\end{array}$ & $\begin{array}{c}1,248,057 \\
(1,287,370)\end{array}$ & $\begin{array}{c}357,028 \\
(147,558)\end{array}$ & $\begin{array}{c}0.0418 \\
(0.0345)\end{array}$ & $\begin{array}{l}10.4500 \\
(7.9310)\end{array}$ & $\begin{array}{c}6.8831 \\
(2.8316)\end{array}$ & $\begin{array}{c}0.2800 \\
(0.5820)\end{array}$ \\
\hline 1998 & $\begin{array}{c}0.7117 \\
(0.5609)\end{array}$ & $\begin{array}{c}0.1491 \\
(0.1460)\end{array}$ & $\begin{array}{c}1,180,301 \\
(1,142,288)\end{array}$ & $\begin{array}{c}363,835 \\
(149,070)\end{array}$ & $\begin{array}{c}0.0463 \\
(0.0434)\end{array}$ & $\begin{array}{l}10.6100 \\
(7.7710)\end{array}$ & $\begin{array}{c}6.8139 \\
(2.6269)\end{array}$ & $\begin{array}{c}0.2900 \\
(0.5990)\end{array}$ \\
\hline 1999 & $\begin{array}{c}0.6733 \\
(0.4427)\end{array}$ & $\begin{array}{c}0.1351 \\
(0.1229)\end{array}$ & $\begin{array}{c}1,133,916 \\
(1,090,142)\end{array}$ & $\begin{array}{c}374,822 \\
(155,585)\end{array}$ & $\begin{array}{c}0.0464 \\
(0.0391)\end{array}$ & $\begin{array}{l}10.8400 \\
(7.9400)\end{array}$ & $\begin{array}{c}7.0306 \\
(2.6414)\end{array}$ & $\begin{array}{c}0.2900 \\
(0.6320)\end{array}$ \\
\hline 2000 & $\begin{array}{c}0.7052 \\
(0.4412)\end{array}$ & $\begin{array}{c}0.1426 \\
(0.1240)\end{array}$ & $\begin{array}{c}1,150,731 \\
(1,085,142)\end{array}$ & $\begin{array}{c}378,673 \\
(200,961)\end{array}$ & $\begin{array}{c}0.0473 \\
(0.0428)\end{array}$ & $\begin{array}{l}10.9900 \\
(7.9460)\end{array}$ & $\begin{array}{c}7.1774 \\
(2.5876)\end{array}$ & $\begin{array}{c}0.2700 \\
(0.6150)\end{array}$ \\
\hline 2001 & $\begin{array}{c}0.8959 \\
(0.7138)\end{array}$ & $\begin{array}{c}0.1709 \\
(0.1729)\end{array}$ & $\begin{array}{c}1,066,005 \\
(1,075,025)\end{array}$ & $\begin{array}{c}380,064 \\
(166,548)\end{array}$ & $\begin{array}{c}0.0615 \\
(0.0713)\end{array}$ & $\begin{array}{l}11.7000 \\
(7.7650)\end{array}$ & $\begin{array}{c}6.8924 \\
(2.6305)\end{array}$ & $\begin{array}{c}0.2100 \\
(0.5600)\end{array}$ \\
\hline 2002 & $\begin{array}{c}0.8830 \\
(0.8268)\end{array}$ & $\begin{array}{c}0.1616 \\
(0.1597)\end{array}$ & $\begin{array}{c}1,040,251 \\
(1,142,093)\end{array}$ & $\begin{array}{c}373,011 \\
(207,806)\end{array}$ & $\begin{array}{c}0.0605 \\
(0.0714)\end{array}$ & $\begin{array}{c}12.3541 \\
(7.588)\end{array}$ & $\begin{array}{c}6.8968 \\
(2.6037)\end{array}$ & $\begin{array}{l}0.2679 \\
(0.668)\end{array}$ \\
\hline 2003 & $\begin{array}{c}1.1429 \\
(1.3718)\end{array}$ & $\begin{array}{c}0.1894 \\
(0.1932)\end{array}$ & $\begin{array}{r}953,837 \\
(832,718)\end{array}$ & $\begin{array}{c}375,672 \\
(242,344)\end{array}$ & $\begin{array}{c}0.0798 \\
(0.1235)\end{array}$ & $\begin{array}{l}13.5332 \\
(8.5330)\end{array}$ & $\begin{array}{c}7.2371 \\
(2.7567)\end{array}$ & $\begin{array}{c}0.2248 \\
(0.5921)\end{array}$ \\
\hline 2004 & $\begin{array}{c}2.5161 \\
(3.8811)\end{array}$ & $\begin{array}{c}0.3011 \\
(0.2669)\end{array}$ & $\begin{array}{c}909,605 \\
(820,027)\end{array}$ & $\begin{array}{c}379,946 \\
(153,818)\end{array}$ & $\begin{array}{c}0.1761 \\
(0.2659)\end{array}$ & $\begin{array}{l}13.8464 \\
(7.9254)\end{array}$ & $\begin{array}{c}6.4546 \\
(2.9512)\end{array}$ & $\begin{array}{c}0.2321 \\
(0.5284)\end{array}$ \\
\hline 2005 & $\begin{array}{c}1.6591 \\
(2.2313)\end{array}$ & $\begin{array}{c}0.2456 \\
(0.2369)\end{array}$ & $\begin{array}{l}1,008,494 \\
(980,983)\end{array}$ & $\begin{array}{c}364,558 \\
(164,060)\end{array}$ & $\begin{array}{c}0.1085 \\
(0.1730)\end{array}$ & $\begin{array}{c}14.3184 \\
(8.1919)\end{array}$ & $\begin{array}{c}7.8868 \\
(2.6920)\end{array}$ & $\begin{array}{c}0.2399 \\
(0.6095)\end{array}$ \\
\hline 2006 & $\begin{array}{c}2.0597 \\
(2.1187)\end{array}$ & $\begin{array}{c}0.2908 \\
(0.2455)\end{array}$ & $\begin{array}{c}1,066,207 \\
(1,072,900)\end{array}$ & $\begin{array}{c}369,952 \\
(163,951)\end{array}$ & $\begin{array}{c}0.1602 \\
(0.2756)\end{array}$ & $\begin{array}{l}15.4439 \\
(8.4002)\end{array}$ & $\begin{array}{c}7.9532 \\
(2.7722)\end{array}$ & $\begin{array}{c}0.2460 \\
(0.6412)\end{array}$ \\
\hline 2007 & $\begin{array}{c}1.7013 \\
(2.4457)\end{array}$ & $\begin{array}{c}0.2534 \\
(0.2413)\end{array}$ & $\begin{array}{l}1,058,179 \\
(968,547)\end{array}$ & $\begin{array}{c}363,824 \\
(150,001)\end{array}$ & $\begin{array}{c}0.1242 \\
(0.3820)\end{array}$ & $\begin{array}{l}15.5822 \\
(8.5404)\end{array}$ & $\begin{array}{c}8.0026 \\
(2.7850)\end{array}$ & $\begin{array}{c}0.2044 \\
(0.5152)\end{array}$ \\
\hline 2008 & $\begin{array}{c}1.4551 \\
(2.3924)\end{array}$ & $\begin{array}{c}0.2240 \\
(0.2214)\end{array}$ & $\begin{array}{c}1,143,793 \\
(1,250,588)\end{array}$ & $\begin{array}{c}372,005 \\
(158,254)\end{array}$ & $\begin{array}{c}0.0896 \\
(0.1757)\end{array}$ & $\begin{array}{l}16.7078 \\
(8.4249)\end{array}$ & $\begin{array}{c}8.2233 \\
(2.9377)\end{array}$ & $\begin{array}{c}0.2593 \\
(0.6786)\end{array}$ \\
\hline $\begin{array}{l}\text { Whole } \\
\text { period }\end{array}$ & $\begin{array}{c}1.0008 \\
(1.4850)\end{array}$ & $\begin{array}{c}0.1764 \\
(0.1811)\end{array}$ & $\begin{array}{c}1,131,629 \\
(1,105,916)\end{array}$ & $\begin{array}{c}358,300 \\
(168,020)\end{array}$ & $\begin{array}{c}0.0673 \\
(0.1448)\end{array}$ & $\begin{array}{l}11.9108 \\
(8.3522)\end{array}$ & $\begin{array}{c}7.2724 \\
(2.9016)\end{array}$ & $\begin{array}{c}0.2600 \\
(0.5942)\end{array}$ \\
\hline
\end{tabular}

Note: TRTA denotes the ratio of total revenue to total assets; ROA denotes returns on assets; $\mathrm{W}_{1}$ denotes unit labor price of partners; $\mathrm{W}_{2}$ denotes unit labor price of non-partners; $\mathrm{W}_{3}$ denotes unit price of the floor area; AGE denotes firm age; $\mathrm{HC}$ denotes human capital; BRANCH denotes the number of branches. 


\section{Empirical Results}

\subsection{Test of Market Competition}

Table 5 presents the estimation result of Equation (4). The Hausman test results indicate that the fixed effect model is appropriate. The adjusted $R^{2}$ 's range between 0.75 and 0.88 , indicating that the goodness of fit is quite strong. Except for $B R A N C H$, the vast majority of parameter estimates reaches the $1 \%$ level of significance in all or some sub-periods.

Table 5. Estimation result of the PR model during 1992-2008: $\ln C R_{5}$

\begin{tabular}{lccccc}
\hline Variable & $1992-2008$ & $1992-1996$ & $1997-2000$ & $2001-2004$ & $2005-2008$ \\
\hline $\ln W_{1}$ & $0.1182^{* * *}$ & $0.1621^{* * *}$ & $0.1588^{* * *}$ & $0.0683^{* * *}$ & $0.0836^{* * *}$ \\
& $(0.0079)$ & $(0.0120)$ & $(0.0126)$ & $(0.0241)$ & $(0.0245)$ \\
$\ln W_{2}$ & $0.1718^{* * *}$ & $0.2386^{* * *}$ & $0.2984^{* * *}$ & $0.1499^{* * *}$ & $0.2572^{* * *}$ \\
& $(0.0173)$ & $(0.0286)$ & $(0.0322)$ & $(0.0468)$ & $(0.0595)$ \\
$\ln W_{3}$ & $0.4577^{* * *}$ & $0.2441^{* * *}$ & $0.2223^{* * *}$ & $0.6529^{* * *}$ & $0.7349^{* * *}$ \\
& $(0.0064)$ & $(0.0117)$ & $(0.0113)$ & $(0.0153)$ & $(0.0142)$ \\
$\ln C R_{5}$ & $0.4177^{* * *}$ & -0.1432 & 0.0428 & $1.1696^{* * *}$ & -0.2506 \\
& $(0.0459)$ & $(0.1467)$ & $(0.0895)$ & $(0.3470)$ & $(0.5154)$ \\
$\ln A G E$ & $0.1477^{* * *}$ & $0.1743^{* * *}$ & $0.1922^{* * *}$ & $0.2944^{* * *}$ & 0.1281 \\
& $(0.0195)$ & $(0.0299)$ & $(0.0512)$ & $(0.0949)$ & $(0.1157)$ \\
$\ln H C$ & $-0.1741^{* * *}$ & $-0.1549^{* * *}$ & $-0.5077^{* * *}$ & -0.0369 & $-0.2711^{* *}$ \\
& $(0.0273)$ & $(0.0444)$ & $(0.0530)$ & $(0.0715)$ & $(0.1117)$ \\
$B R A N C H$ & -0.0141 & -0.0158 & $-0.1126^{* * *}$ & -0.0100 & -0.0798 \\
Hausman test & $(0.0202)$ & $(0.0372)$ & $(0.0367)$ & $(0.0479)$ & $(0.0569)$ \\
${ }_{R}^{2}$ & $113.87^{* * *}$ & $31.253^{* *}$ & $18.999^{*}$ & $184.12^{* * *}$ & $179.00^{* * *}$ \\
$H=0$ & 0.7542 & 0.8112 & 0.8535 & 0.8260 & 0.8760 \\
$H=1$ & $0.7477^{* * *}$ & $0.6447^{* * *}$ & $0.6795^{* * *}$ & $0.8711^{* * *}$ & $1.0756^{* * *}$ \\
Sample size & $-0.2523^{* * *}$ & $-0.3553^{* * *}$ & $-0.3205^{* * *}$ & $-0.1289^{* * *}$ & 0.0756 \\
& 8,265 & 2,307 & 2,355 & 1,847 & 1,756
\end{tabular}

Note: 1 . Numbers in parentheses are standard errors.

2. *, **, and $* * *$ denote significance at the $10 \%, 5 \%$, and $1 \%$ levels, respectively.

Over the whole period (1992-2008), the H-statistic is significantly greater than 0 and smaller than 1 at the $1 \%$ level. In other words, the accounting industry exhibited a monopolistic competition structure during the entire sample period. After dividing the period into four sub-periods, we observe a gradual increase in the H-statistic (from 0.6447 to $0.6795,0.8711$, and 1.0756). The null hypothesis of $\mathrm{H}=0$ is rejected in all the four sub-periods at the $1 \%$ level. The null hypothesis of $\mathrm{H}=1$ is rejected in all but the last period. In other words, the accounting industry had a monopolistic competition structure during the first three sub-periods and gradually developed toward perfect competition. The above results are consistent with the actual trend of the development in Taiwan's accounting industry. Conversely, the structural indices, $\mathrm{CR}_{5}, \mathrm{CR}_{10}$, and $\mathrm{HHI}$, increased steadily over time, implying a growing market concentration and a declining market competition. This is inconsistent with the tendency found by the $\mathrm{H}$-statistics and actual market conditions as well.

Among the control variables, the effect of $\mathrm{CR}_{5}$ on total revenue is significantly positive only in the whole period and the sub-period 2001-2004 (0.4177 and 1.1696) and is insignificant in the remaining three sub-periods. Positive $\mathrm{CR}_{5}$ values suggest that CPA firms can use their market power to raise their revenues, conforming to the SCP hypothesis. In the remaining three sub-periods, although the top five CPA firms had an increasing market share, they did not increase their auditing fees and total revenue. This outcome is congruent with the contestable market hypothesis.

The traditional structural approach generally supports that competition in Taiwan's public accounting industry has 
been declining, leading the market toward monopolistic or oligopolistic competition. In contrast, the non-structural approach reveals that this industry has had a monopolistic competition structure, but is evolving toward perfect competition. The two approaches produce divergent results. According to Shaffer (2004), the PR approach is more reliable than the structural approach as it directly assesses firm conduct. Therefore, we conclude that Taiwan's public accounting industry can be characterized as monopolistic competition during the sample period, while gradually adjusting toward perfect competition. This conclusion conforms to the actual conditions of the industry.

In addition to $\mathrm{CR}_{5}$, we also use $\mathrm{CR}_{10}$ or $\mathrm{HHI}$ as a market concentration index in Equation (4). The results are similar to those of $\mathrm{CR}_{5}$ and hence are not reported to save space. The detailed results are available from the authors upon request.

\subsection{Test of Long-run Equilibrium}

We now turn to the test for long-run equilibrium using the $\mathrm{H}$ statistic. To ensure that all the firms have a positive ROA for regression analysis, we add 6 to the ROA of each firm before calculating the logarithm of ROA. According to the Hausman test results, we choose the fixed effect model. After obtaining the parameter estimates, we test the hypothesis of $\mathrm{E}=0$ in (7). Table 6 presents all the estimation results. It is seen that the $\mathrm{E}$ statistics in the entire sample period and all individual sub-periods attain the $1 \%$ significance level, implying that the market was not in long-run equilibrium.

Table 6. Testing results of long-run equilibrium

(All ROAs are adjusted by adding 6 before taking the natural logarithm)

\begin{tabular}{lccccc}
\hline Variable & $1992-2008$ & $1992-1996$ & $1997-2000$ & $2001-2004$ & $2005-2008$ \\
\hline $\ln W_{1}$ & $0.0109^{* * * *}$ & $0.0094^{* * * *}$ & $0.0108^{* * * *}$ & $0.0112^{* * *}$ & $0.0171^{* * *}$ \\
& $(32.6948)$ & $(20.3561)$ & $(21.5155)$ & $(9.6236)$ & $(13.6353)$ \\
$\ln W_{2}$ & $-0.0013^{*}$ & -0.0012 & -0.0009 & -0.0011 & $0.0085^{* * *}$ \\
& $(-1.7940)$ & $(-1.1230)$ & $(-0.6919)$ & $(-0.5077)$ & $(2.7893)$ \\
$\ln W_{3}$ & $0.0120^{* * *}$ & $0.0050^{* * *}$ & $0.0047^{* * *}$ & $0.0174^{* * *}$ & $0.0230^{* * *}$ \\
& $(44.0617)$ & $(11.0924)$ & $(10.3778)$ & $(23.3815)$ & $(31.5194)$ \\
$\ln C R_{5}$ & $0.0200^{* * *}$ & -0.0054 & -0.0038 & $0.0463^{* * *}$ & -0.0032 \\
& $(10.2672)$ & $(-0.9600)$ & $(-1.0676)$ & $(2.75930)$ & $(-0.1228)$ \\
$\ln A G E$ & -0.0014 & -0.0018 & 0.0028 & $0.0105^{* * *}$ & 0.0027 \\
& $(-1.6393)$ & $(-1.5990)$ & $(1.3817)$ & $(2.2840)$ & $(0.4521)$ \\
$\ln H C$ & $0.0051^{* * *}$ & 0.0027 & 0.0015 & $0.0083^{* * *}$ & -0.0073 \\
& $(4.3795)$ & $(1.5961)$ & $(0.7054)$ & $(2.4103)$ & $(-1.2669)$ \\
$B R A N C H$ & -0.0012 & -0.0011 & -0.0020 & -0.0004 & -0.0037 \\
Hausman test: & $(-1.4409)$ & $(-0.8026)$ & $(-1.3963)$ & $(-0.1613)$ & $(-1.2523)$ \\
$\bar{R}^{2}$ & $161.63^{* * *}$ & $29.5980^{* * *}$ & $17.843^{* *}$ & $113.75^{* * *}$ & $164.80^{* * *}$ \\
$E=0$ & 0.6069 & 0.7292 & 0.7784 & 0.6454 & 0.7647 \\
$(p$ value $)$ & $(<0.0001)$ & $(<0.0001)$ & $(<0.0001)$ & $(<0.0001)$ & $(<0.0001)$ \\
Sample size & 8,265 & 2,307 & 2,355 & 1,847 & 1,756 \\
\hline
\end{tabular}

Table 7 shows the estimation result obtained from the CSF model. Recall that the CSF model does not require adjusting ROAs before taking the natural logarithm. The information embedded in the sample is less likely to be distorted. The E statistics are found to be significantly different from zero in the whole period and in the first two sub-periods, 1992-1996 and 1997-2000, meaning that the accounting industry did not achieve long-run equilibrium in those sub-periods. However, the E statistics are insignificantly different from zero in the last two sub-periods, 2001-2004 and 2005-2008, suggesting that the industry was in long-run equilibrium in these two sub-periods. 
Table 7. Test for long-run equilibrium of Taiwan's public accounting industry during 1992-2008 (CSF)

\begin{tabular}{|c|c|c|c|c|c|}
\hline Variable & $1992-2008$ & 1992-1996 & $1997-2000$ & 2001-2004 & $2005-2008$ \\
\hline \multirow{2}{*}{ Constant } & $-6.6534^{* * *}$ & $-7.0732^{* * *}$ & $-2.0350^{* * *}$ & $-27.2655^{* *}$ & -2.7387 \\
\hline & $(-31.1233)$ & $(-2.7309)$ & $(-3.6145)$ & $(-2.3674)$ & $(-0.6132)$ \\
\hline \multirow{2}{*}{$\ln W_{1}$} & $0.9589^{* * * *}$ & $0.9840^{* * * *}$ & $0.9679^{* * *}$ & $0.6592^{* *}$ & $0.1832^{* * *}$ \\
\hline & $(63.2217)$ & $(24.8452)$ & $(57.3811)$ & (2.2925) & $(5.4357)$ \\
\hline \multirow{2}{*}{$\ln W_{2}$} & $-0.9829^{* * *}$ & $-0.4014^{* * *}$ & $-1.0749^{* * *}$ & -0.0435 & $-0.1898^{* *}$ \\
\hline & $(-68.9741)$ & $(-5.8515)$ & $(-29.6249)$ & $(-0.1022)$ & $(-2.5827)$ \\
\hline \multirow{2}{*}{$\ln W_{3}$} & $0.2883^{* * *}$ & $0.1937^{* * *}$ & $0.1873^{* * *}$ & 0.1163 & $0.1031^{* * *}$ \\
\hline & (14.5785) & (9.1087) & (15.6182) & $(0.9328)$ & $(7.6830)$ \\
\hline \multirow{2}{*}{$\ln C R_{5}$} & $1.2677^{* * *}$ & -0.5752 & $0.2020^{* * *}$ & 4.5244 & 0.5471 \\
\hline & (53.2669) & $(-0.8642)$ & (10.2683) & $(0.9650)$ & $(0.5566)$ \\
\hline \multirow{2}{*}{$\ln A G E$} & $-0.0466^{*}$ & 0.0217 & $-0.1560^{* * * *}$ & -0.1604 & 0.0020 \\
\hline & $(-1.7660)$ & $(0.5504)$ & $(-7.0533)$ & $(-0.7253)$ & $(0.0327)$ \\
\hline \multirow{2}{*}{$\ln H C$} & $0.6724^{* * *}$ & $0.4675^{* * *}$ & $0.8207^{* * *}$ & 0.6625 & $0.3138^{* *}$ \\
\hline & (19.2527) & $(4.9315)$ & (10.0807) & $(0.7794)$ & (2.2933) \\
\hline \multirow{2}{*}{ BRANCH } & $-0.1362^{* * *}$ & $-0.7705^{* * *}$ & $0.4573^{* * *}$ & -0.2114 & 0.0750 \\
\hline & $(-6.0088)$ & $(-12.1133)$ & $(6.9444)$ & $(-1.0966)$ & $(0.4542)$ \\
\hline$\lambda=\sigma_{u} / \sigma_{v}$ & $1.4838^{* * *}$ & $2.2545^{* * *}$ & $1.8809^{* * *}$ & $3.2632^{* *}$ & $4.3544^{* * *}$ \\
\hline$\sigma^{2}=\sigma_{u}^{2}+\sigma_{v}^{2}$ & $0.5051^{* * *}$ & $1.6566^{* * *}$ & $0.6017^{* * *}$ & $2.9093^{* * *}$ & 2.8980 \\
\hline$E=0$ & $0.2642^{* * *}$ & $0.7763^{* * *}$ & $0.0803^{* *}$ & $0.7320(0.209)$ & 0.0965 \\
\hline ( $p$ value $)$ & $(<0.0001)$ & $(<0.0001)$ & $(0.031)$ & & $(0.104)$ \\
\hline Sample size & 8,265 & 2,307 & 2,355 & 1,847 & 1,756 \\
\hline Log-likelihood & $-12,068.8$ & $-3,953.0$ & $-3,390.95$ & $-3,761.51$ & $-3,540.08$ \\
\hline
\end{tabular}

The results in Table 7 differ from those in Table 6. After applying the CSF model to deal with negative ROAs, we obtain a different conclusion. Table 7 indicates that the industry has achieved long-run equilibrium in the last two sub-periods. Therefore, the market competition test results shown in Table 5 are meaningful for those two sub-periods.

\section{Conclusions}

In this paper we assess the degree of competition in Taiwan's public accounting industry and examine whether the competitive conditions vary over time or are affected by policy changes. Both the structural and non-structural PR approaches are applied for the purpose of comparison. Our findings are summarized as follows. First, the traditional structural approach produces results confirming that this industry was evolving toward an oligopoly or monopoly, but the non-structural approach suggests that the industry has gone from monopolistic competition to perfect competition. According to Shaffer (2004), the results of the PR model are more reliable and meaningful to policy makers.

The PR model is built on the condition of long-run equilibrium. By applying the CSF model to handle negative ROAs, we empirically find that the accounting industry in Taiwan is not in long-run equilibrium during the first half of the sample period, but achieves long-run equilibrium during the second half. This result also implies that some structural changes might have occurred during the sample period, and it would be better to divide the sample period into sub-periods for more accurate analysis. Moreover, the traditional method of adjusting negative ROAs into positive values might have distorted the sample information, which may bias the parameter estimates and the subsequent test for long-run equilibrium. Our findings highlight the importance and usefulness of CSF, especially when the dependent variable has a negative value and one cannot take its natural logarithm. 
It is known that the PR model can be used to estimate a single $\mathrm{H}$ value for the entire sample, instead of for individual observations like the measure of Lerner index. Consequently, the $\mathrm{H}$ value cannot be applied to further analyze, e.g., the nexus between efficiency scores (profitability, $\mathrm{Z}$ score, innovations) and the index of market competition. It is suggested that academic researchers employ the Lerner index for future studies.

\section{References}

Al-Muharrami, S., Matthew, K. \& Khabari, Y. (2006). Market Structure and Competitive Conditions in the Arab GCC Banking System. Journal of Banking and Finance, 30(12), 3487-3501. https://doi.org/10.1016/j.jbankfin.2006.01.006

Banker, R. D., Chang, H. \& Cunningham, R. (2003). The Public Accounting Industry Production Function. Journal of Accounting \& Economics, 35(2), 255-281. https://doi.org/10.1016/S0165-4101(03)00021-1

Banker, R. D., Chang, H. \& Natarajan, R. (2005). Productivity Change, Technical Progress, and Relative Efficiency Change in the Public Accounting Industry. Management Science, 51(2), 291-304. https://doi.org/10.1287/mnsc.1040.0324

Baumol, W. (1982). Contestable Markets: An Uprising in the Theory of Industry Structure. The American Economic Review, 72(1), 1-15.

Bikker, J. A. \& Haaf, K. (2002). Competition, Concentration and the Relationship: an Empirical Analysis of the Banking Industry. Journal of Banking and Finance, 26(11), 2191-2214. https://doi.org/10.1016/S0378-4266(02)00205-4

Bresnahan, T. F. (1982). The Oligopoly Solution is Identified. Economics Letters, 10, 87-92. https://doi.org/10.1016/0165-1765(82)90121-5

Casu, B., \& Girardone, C. (2006). Bank Competition, Concentration and Efficiency in the Single European Market. The Manchester School, 74(4), 441-68. https://doi.org/10.1111/j.1467-9957.2006.00503.x

Cavalluzzo, K. (2002). Competition, fee-for-service requirements, and government performance: evidence on the Federal Reserve. Journal of Accounting and Public Policy, 21(4-5), 315-356. https://doi.org/10.1016/S0278-4254(02)00065-0

Demsetz, H. (1974). Two systems of belief about monopoly, in H. J. Goldschmid, H. M. Mann and J. F. Weston (eds.), Industrial Concentration: the New Learning, Boston, MA, Little Brown, 164-184.

Gilbert, A. R. (1984). Bank market structure and competition: A survey. Journal of Money, Credit, and Banking, 16, 617-645. https://doi.org/10.2307/1992096

Gruben, W. C. \& McComb, R. P. (2003). Privatization, competition, and supercompetition in the Mexican commercial banking system. Journal of Banking and Finance, 27(2), 229-249. https://doi.org/10.1016/S0378-4266(01)00218-7

Hannan, H. T. (1991). Foundations of the structure-conduct-performance paradigm in banking. Journal of Money, Credit, and Banking, 23, 68-84. https://doi.org/10.2307/1992764

Huang, T. H. \& Liu, N. H. (2014). Bank Competition in Transition Countries: Are Those Markets Really in Equilibrium? Empirical Economics, 47, 1283-1316. https://doi.org/10.1007/s00181-013-0778-2

Lau, L. J. (1982). On identifying the degree of competitiveness from industry price and output data. Economics Letters, 10, 93-99. https://doi.org/10.1016/0165-1765(82)90122-7

Molyneux, P., Thornton, J. \& Lloyd-Williams, D. M. (1996). Competition and Market Contestability in Japanese Commercial Banking. Journal of Economics and Business, 48, 33-45. https://doi.org/10.1016/0148-6195(95)00047-X

Nathan, A. \& Neave, H. (1989). Competition and Contestability in Canada's Financial System: Empirical Results. Canadian Journal of Economics, 22, 576-594. https://doi.org/10.2307/135541

Panzar, J. C., \& Rosse, J. N. (1987). Testing for Monopoly Equilibrium. Journal of Industrial Economics, 35 (4), 443-456. https://doi.org/10.2307/2098582

Rosse, J. N. \& Panzar, J. C. (1977). Chamberlin versus Robinson: An empirical test for monopoly rents. Studies in Industry Economics, Research Paper, 77.

Schaeck, K., Cihak, M. \& Simon, W. (2009). Are competitive banking systems more stable? Journal of Money, 
Credit, and Banking, 41, 711-734. https://doi.org/10.1111/j.1538-4616.2009.00228.x

Shaffer, S. (1982). A Nonstructural Test for Competition in Financial Markets. Proceedings of a Conference, 225-243.

Shaffer, S. (1999). The competitive impact of disclosure requirements in the credit card industry. Journal of Regulatory Economics, 15, 183-198. https://doi.org/10.1023/A:1008081828166

Shaffer, S. (2001). Banking conduct before the European single banking license: A cross-country comparison. North American Journal of Economics and Finance, 12, 79-104. https://doi.org/10.1016/S1062-9408(01)00041-9

Shaffer, S. (2004). Patterns of competition in banking. Journal of Economics and Business, 56, 287-313. https://doi.org/10.1016/j.jeconbus.2003.10.003

Simunic, D. A. (1980). The Pricing of Audit Services: Theory and Evidence. Journal of Accounting Research, 18(1), 161-190. https://doi.org/10.2307/2490397

Sunder, S. (2002). Regulatory competition for low cost-of-capital accounting rules. Journal of Accounting and Public Policy, 21, 147-149. https://doi.org/10.1016/S0278-4254(02)00045-5

Tsay, W. J., Huang, C. J., Fu, T. T., \& Ho, I. L. (2013). A simple closed-form approximation for the cumulative distribution function of the composite error of stochastic frontier models. Journal of Productivity Analysis, 39, 259-269. https://doi.org/10.1007/s11123-012-0283-1 